\title{
Accounting Theory and Its Impact on Adoption of Sustainability Reporting Dimensions - A Field Study
}

\author{
Ammar Daher Mamdouh Bashatweh \\ The World Islamic Sciences and Education University Dept. of Accounting \\ Amman, Jordan
}

Tel: 96-2797-942-007Ｅ-mail: bashatwahammar@yahoo.com

\author{
Received: October 3, $2018 \quad$ Accepted: October 20, $2018 \quad$ Published: October 24, 2018 \\ doi:10.5296/ijafr.v8i4.13736 \\ URL: https://doi.org/10.5296/ijafr.v8i4.13736
}

\begin{abstract}
The main objective of the study was to identify the effect of the adoption of accounting theories (agency theory, signaling theory, theory of legitimacy, stockholders theory) in the disclosure of sustainability dimensions (economic dimension, environmental dimension, social dimension). To achieve the objective of the study, the sample of the study included Jordanian public shareholding companies which belong to the financial, industrial and service sectors. The study sample consisted of 20 public shareholding companies distributed among various sectors.

The study found out that is a statistically significant effect on the adoption of accounting theories in the disclosure of sustainability dimensions when studying the dimensions combined. The study recommended the need to increasing the commitment of public shareholding companies to apply the principle of transparency and disclosure of their environmental, social and economic activities, as well as recommending the management of public shareholding companies to the necessity of diversity in the interests of all parties associated with them.
\end{abstract}

Keywords: Sustainability reports, Accounting theories, Economic dimension, Environmental dimension, Social dimension

\section{Introduction}

Even though the number of sustainability reports continues to mount, it is difficult for external users to take a look behind the scenes' to see how sustainability issues are truly incorporated in the daily business of the company and what significance it has for the 
operations of the company, The awareness of sustainability is increasingly gaining weight in the international debate (Thomas \& Vos, 2012) IFAC is concerned about the sustainability issue. IFAC President Olivia Kartley said that businesses are flexible when they are able to create and continue to deliver values to stakeholders, including taking into account the risks and opportunities offered by sustainability issues, including environmental dimension And social impact on financial performance and value creation (Bashatweh, 2018).

Theories are abstractions of reality and hence particular theories cannot be expected to provide a full account or description of particular behavior.

It is sometimes useful to consider the perspectives provided by alternative theories. Different researchers might study the same phenomenon but elect to adopt alternative theoretical perspectives.

1. Since there is an abstraction

2. Then there is a lack of completeness

3. Which in turn requires looking at different perspectives or alternatives

4. In order to have a wider insight

Legitimacy theory, stakeholder theory and institutional theory are three theoretical perspectives that have been adopted by a number of researchers in recent years. Within legitimacy theory, stakeholder theory and institutional theory, accounting disclosure policies are considered to constitute a strategy to influence the organization's relationships with the other parties with which it interacts. In recent times, stakeholder theory and legitimacy theory have been applied primarily to explain why organizations make certain social responsibility disclosures within their annual reports (Deegan \& Unerman, 2011, 321).

\subsection{Question of the Study}

In light of changes and increased interest in the disclosure, Moves towards sustainable require organizations to explicitly consider various facets of their economic, social and environmental performance, corporate annual reports no longer focus solely on the accounts quantitative information but volunteer qualitative information about a variety of topics such as sustainability. This study is a response to the need of users of financial statements to know the interest in the dimensions of sustainability as result to change in the business environment and competition. However, there is paucity of research works in this area of study in Jordan. So the study seeks to examine the effect of accounting theories (agency theory, signaling theory, theory of legitimacy, stockholders theory) adoption on disclosure of sustainability dimensions (economic dimension, environmental dimension, social dimension) in public shareholding companies by trying to answer the following question:

\subsubsection{The Main Question}

Is there a significant effect of the adoption of accounting theories (agency theory, signaling theory, legitimacy theory, and stakeholder theory) on disclosing of sustainability dimensions (economic dimension, environmental dimension, and social dimension) in public 


\section{MlMacrothink}

shareholding companies?

\subsubsection{The Follow up Question}

1. Is there a significant effect of the adoption of accounting theories (agency theory, signaling theory, legitimacy theory, stakeholder theory) on disclosing the economic dimensions in public shareholding companies?

2. Is there a significant effect of the adoption of accounting theories (agency theory, signaling theory, legitimacy theory, stakeholder theory) on disclosing the environmental dimensions in public shareholding companies?

3. Is there a significant effect of the adoption of accounting theories (agency theory, signaling theory, legitimacy theory, stakeholder theory) on disclosing the social dimensions in public shareholding companies?

\subsection{Objective of the Study}

This study aims at:

1. Identify effect on the adoption of accounting theories (agency theory, signaling theory, legitimacy theory, stakeholder theory) on disclosing the economic dimensions in public shareholding companies.

2. Identify effect on the adoption of accounting theories (agency theory, signaling theory, legitimacy theory, stakeholder theory) on disclosing the environmental dimensions in public shareholding companies.

3. Identify effect on the adoption of accounting theories (agency theory, signaling theory, legitimacy theory, stakeholder theory) on disclosing the social dimensions in public shareholding companies.

\subsection{Significance of the Study}

The sustainability reports plays important role in the success of the organization to achieve competitive advantage. The importance of this study lies in expanding the literature on this area. Which will contribute to fill the gap in this type of studies, where the researcher noted the absence of studies linking the theories of accounting and disclosure about sustainability reports dimensions, which will give contribution value to research and It is expected that the research findings will be beneficial to banks, shareholders, would-be investors, academics and the general reading public

\section{Literature Review}

\subsection{Sustainability}

To begin with, the landmark definition of 'sustainability' in the Brundtland Report (WECD, 1987) also forms the basis for an adequate description of CS. It defines sustainable development as a development that meets the needs of the present without compromising the ability of future generations to meet their own needs. Transferring this idea to the business 
level, CS can accordingly be defined as meeting the needs of a firm's direct and indirect stakeholders (such as shareholders, employees, clients, pressure groups, communities, etc.), without compromising its ability to meet the needs of future stakeholders as well (Thomas \& vos, 2012).

Establishing in 1997, the first version of GRI was published in 2000 and second generation was unveiled at the world summit on sustainable development in 2002 at Johannesburg. The third versions, known as G3 published in 2006 and were updated to G3.1, expanding guidance on local community aspects, human rights and gender in 2011. Again, in 2010 GRI launched its fourth generation guideline known as G4. Recently in October 2016, GRI published new version known as GRI Standards which will be effective after June 2018 (Akhter \& Dey, 2017).

\subsection{Sustainability Reports}

Based on the Global Reporting Initiative (GRI, 2014):

- Definition of sustainability reports: reporting that provides information about the economic, environmental and social performance of an entity.

- Vision: A thriving global community that lifts humanity and enhances the resources on which all life depends.

- Mission: To empower decisions that creates social, environmental and economic benefits for everyone.

- Sustainability Dimensions:

a) Environmental dimensions: provides information about such things as: materials usage; water usage; emissions, effluents and waste; compliance with environmental regulations; and use and impact of transport.

b) Economic dimensions: provides information about such things as: Economic Performance, Market Presence, and Procurement Practices.

c) Social dimensions: provides information about such things as:

- Labour practices and decent work performance: Employment, Labor/ Management Relations, Occupational Health and Safety, and Training and Education.

- Human rights: Non-discrimination, Freedom of Association Collective, Child Labor, Forced Labor, and Security Practices.

- Product responsibility performance: Customer Health and Safety, Product Labeling, Marketing Communications, and Customer Privacy

\subsection{Accounting Theory}

In the beginning of the 20th century, specifically in 1916, the researcher William Paton made his first attempt at constructing the theory based on different scientific origins. To build accounting theory uses the deductive approach. In addition, John Canning studied accounting 
thought through economic theory, tried to adapt economic approaches to accounting uses, and Montgomery also had the greatest impact on a theory of auditing. The efforts of researcher Steven Gillman, Kathy (Littleton) is considered one of the most important pioneers in the construction of accounting theory. He published a book entitled "The Structure of Accounting Theory". In 1940, the researcher published another book that was a milestone in the history of intellectual accounting. This is on the part of researchers and thinkers accounting. On the one hand, organizations and professional associations have had a clear impact on the construction of accounting theory, including the Association of American Accountants (AAA), the American Accountants Association (NICPA), the UK Professional Council, and the International Professional Councils (Shahin, 2011, 42).

The definition from Oxford English Dictionary provided in the (Deegan \& Unerman, 2011, 2) textbook defines a theory as: 'A scheme or system of ideas or statements held as an explanation or account of a group of facts or phenomena; a hypothesis that has been confirmed or established by observation or experiment, and is propounded or accepted as accounting for the known facts; a statement of what are held to be the general laws, principles, or causes of something known or observed'.

Sustainability accounting is based on several theories, these theories are as follows:

1. Agency theory: explained why the selection of particular accounting methods might matter and focused on the relationships between principals and agents, Organizations are voluntarily disclosing additional data to reduce the cost of Agency, including those related to social responsibility. Disclosure of corporate social responsibility activities helps to provide investors and financiers with a more accurate assessment of the company and helps the organization attract new investors and helps to obtain financing at a lower cost (Jizi et al., 2014).

2. Signaling theory: suggests that in situations of asymmetric distribution of information, one party tries to credibly convey information about itself to a second party (Hahn \& Kuhnen, 2013) According to this theory, organizational managers use voluntary disclosure, which includes the disclosure of social responsibility and the exploitation of asymmetry in the market to send specific signals to the market showing the good performance of their companies. The theory of indicates that higher-profit organizations have a stronger incentive to increase the volume of voluntary disclosure of information To distinguish itself from others by showing their profitability to investors compared to less profitable organizations as well as to avoid the low valuation of their shares, so as to benefit the management in order to maintain their administrative positions and increase their incentives (Bhattacharya \& Ritter, 1983).

3. Legitimacy theory: According to legitimacy theory, a company needs to have legitimacy in the sense of a social license to operate to access the necessary resources to successfully conduct business. Legitimacy theory suggests that no organization has an inherent right to exist but that any business operation is subject to a greater acceptance granted by society. Such legitimacy, however, is potentially threatened if society perceives that a company is not operating in an acceptable way. Accordingly, legitimation strategies aim at securing 
legitimacy as a valuable resource itself. Considered The preparing sustainability reports as a social contract between the organization, the environment and the society in which it operates gives it the legal legitimacy to own and use natural resources and to exploit human resources, taking into account local laws and regulations (Deegan \& Unerman, 2011, 324)

4. Stakeholder theory: suggests that businesses have to take into account different perspectives and expectations of a wide group of constituents having an interest in corporate activities, researchers describe stakeholder theory as the dominant and most useful theory in explaining sustainability reporting practice, argues that managers need to recognize shifts in the environment among internal and external stakeholders. The recent trend to embrace sustainability issues in society can be regarded (Hahn \& Kuhnen, 2013).

\subsection{Literature Review}

(Senger, Varoglu, \& Karapolatgil, 2015) Due to the importance of stakeholders for the sustainability of the companies, there exists a research interest to identify the important stakeholders. With this study, most salient and other groups of stakeholders were identified based on a content analysis of sustainability reports of 78 large-scale companies. Although many researches are undertaken in developed countries based on sustainability reports that are popular tools for information disclosure for the companies, similar research in developing countries is still at infancy. The findings of the study indicate shareholders and government to be the most salient stakeholders regardless of industry difference.

(Hummel \& Schlick, 2016) The relationship between sustainability performance and sustainability disclosure remains ambiguous, both theoretically and empirically. Voluntary disclosure theory would suggest that the relationship should be positive, whereas legitimacy theory points toward a negative relationship. However, the empirical evidence regarding this relationship is mixed, which indicates that the two theories are not necessarily contradictory but that they are instead two sides of the same coin. This paper refines the theoretical reasoning associated with the two theories and provides empirical evidence for their reconciliation by moving the focus of inquiry from the quantity of sustainability disclosure toward its quality. Our results reveal that consistent with voluntary disclosure theory superior sustainability performers choose high-quality sustainability disclosure to signal their superior performance to the In addition, based on legitimacy theory, poor sustainability performers prefer low-quality sustainability disclosure to disguise their true performance and to simultaneously protect their legitimacy. The results remain robust to various additional analyses. Thus, the paper indicates that the two theories dovetail with one another by redirecting the focus toward the quality of sustainability disclosure.

(Hörisch, Freeman, \& Schaltegger, 2014) This essay examines links, similarities, and dissimilarities between stakeholder theory and sustainability management. Based on the analysis a conceptual framework is developed to increase the applicability and the application of stakeholder theory in sustainability management. Concluding from the analysis, we identify three challenges of managing stakeholder relationships for sustainability: strengthening the particular sustainability interests of stakeholders, creating mutual sustainability interests based on these particular interests, and empowering stakeholders act as 


\section{Ml Macrothink}

International Journal of Accounting and Financial Reporting

ISSN 2162-3082

2018, Vol. 8, No. 4

intermediaries for nature and sustainable development. To address these challenges three interrelated mechanisms are suggested: education, regulation, and sustainability-based value creation for stakeholders.

(Hahn, \& Kuhnen, 2013) This paper provides a review of 178 articles dating from 1999 to 2011 from journals related to business, management, and accounting. Our aim is to identify what determinants of sustainability reporting are examined in the literature and to identify (in) consistencies, gaps, and opportunities for future research. We specifically illuminate factors influencing the adoption, the extent, and the quality of reporting. Based on our findings we provide an otherwise often missing link to theory (especially legitimacy, stakeholder, signaling, and institutional theory). Finally, possible future research themes are discussed by illuminating gaps and underexposed themes in the area of regulation and governance as well as reporting quality and stakeholder perception. Our aim is to identify what determinants of sustainability reporting are examined in the literature and to identify (in) consistencies, gaps, and opportunities for future research. We specifically illuminate factors influencing the adoption, the extent, and the quality of reporting. Based on our findings we provide an otherwise often missing link to theory (especially legitimacy, stakeholder, signaling, and institutional theory).

(Deegan, 2002) This paper an issue which embraces themes associated with social and environmental reporting (SAR) and its role in maintaining or creating organizational legitimacy. In an effort to place this research in context the paper begins by making reference to contemporary trends occurring in social and environmental accounting research generally, and this is then followed by an overview of some of the many research questions which are currently being addressed in the area. Understanding motivations for disclosure is shown to be one of the issues attracting considerable research attention, and the desire to legitimise an organization's operations is in turn shown to be one of the many possible motivations. The role of legitimacy theory in explaining managers' decisions is then discussed and it is emphasized that legitimacy theory, as it is currently used, must still be considered to be a relatively under - developed theory of managerial behavior. Nevertheless, it is argued that the theory provides useful insights.

\section{Framework of the Study}

Independent Variables

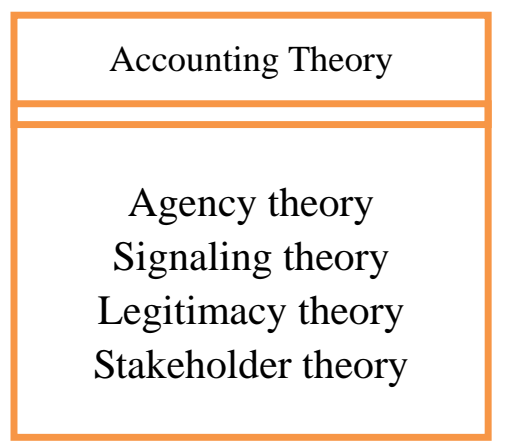

Dependent Variables

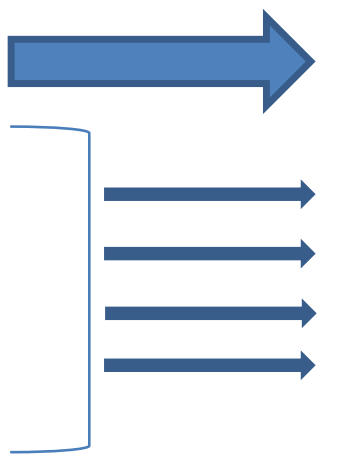

Sustainability Dimensions

Economic dimensions

Environmental dimensions

Social dimensions

Figure 1. Study framework / research design 


\section{Mll Macrothink}

International Journal of Accounting and Financial Reporting

ISSN 2162-3082 2018, Vol. 8, No. 4

\subsection{Hypotheses of the Study}

To address the case study objectives, the following assumptions were formulated of the:

The main hypotheses:

There is no statistically significant at the (0.05) level for the adoption of accounting theories (agency theory, signaling theory, legitimacy theory, stakeholder theory) on disclosing of sustainability dimensions (economic dimension, environmental dimension, and social dimension) in public shareholding companies.

The main assumption leads to the following assumptions:

H1. There is no statistically significant at the (0.05) level for the adoption of accounting theories (agency theory, signaling theory, legitimacy theory, stakeholder theory) on disclosing the economic dimensions in public shareholding companies.

H2. There is no statistically significant at the (0.05) level for the adoption of accounting theories (agency theory, signaling theory, legitimacy theory, stakeholder theory) on disclosing the environmental dimensions in public shareholding companies.

H3. There is no statistically significant at the (0.05) level for the adoption of accounting theories (agency theory, signaling theory, legitimacy theory, stakeholder theory) on disclosing the social dimensions in public shareholding companies.

\subsection{Population and Sample}

The study population consists of the public shareholding companies which belong to the financial sector ( banks and insurance companies ) and industrial and service companies which number (270) companies, the study sample consisted (20) public shareholding companies, the researcher distributed (100) questionnaires to general and financial directors, their deputies and members of the board of directors of public shareholding companies. Only (95) questionnaires were returned revealing $95 \%$ response rate.

\subsection{Data Collection}

In order achieve the aim of the study the descriptive and analytical approach was utilized. The study relied on two main sources for data collection: for the collection of secondary data: study utilized the previous studies, books periodicals scientific journals, and publications related to the subject of study. As for primary data, the study utilized the questionnaire designed to collect the data needed for the study.

\section{Data Analysis Methods}

The researcher used the Statistical Software Package for Social Sciences (SPSS) to analyze and testing of hypotheses using the following statistical tools such as: Cronbach alpha, descriptive statistics and the hypotheses were examined by Multiple Regression.

\subsection{Sample Characteristics}

This section describes the demographic characteristics of the study sample. To describe the 


\section{1) Macrothink}

International Journal of Accounting and Financial Reporting

ISSN 2162-3082

2018, Vol. 8, No. 4

characteristics of the sample of the study, the frequency and percentage of the demographic variables were found for the sample of the study as follows:

Table 1. Demographic profile of the respondents

\begin{tabular}{|c|c|c|c|}
\hline Category & & Frequency & Percentage $(\%)$ \\
\hline \multicolumn{4}{|l|}{ Education } \\
\hline & Bachelor degree & 44 & $46.30 \%$ \\
\hline & high Diploma & 11 & $11.60 \%$ \\
\hline & Master degree & 36 & $37.90 \%$ \\
\hline & $\mathrm{PhD}$ & 4 & $4.20 \%$ \\
\hline Total & & 95 & $100 \%$ \\
\hline \multicolumn{4}{|l|}{$\begin{array}{l}\text { Years } \\
\text { Experience }\end{array}$} \\
\hline & less than 7 & 7 & $7.40 \%$ \\
\hline & 7 to 15 & 33 & $34.70 \%$ \\
\hline & 15 to 25 & 42 & $44.20 \%$ \\
\hline & more than 25 & 13 & $13.70 \%$ \\
\hline Total & & 95 & $100 \%$ \\
\hline \multicolumn{4}{|l|}{ Position } \\
\hline & General manager / Deputy & 20 & $21.10 \%$ \\
\hline & finance manager / Deputy & 39 & $41.10 \%$ \\
\hline & Board of directors & 36 & $37.80 \%$ \\
\hline Total & & 95 & $100 \%$ \\
\hline
\end{tabular}

Table 1 show that $46.30 \%$ of the sample held a Bachelor degree. Those with a master's degree were only $37.90 \%$, and the remaining either had high diploma $11.60 \%$ and $\mathrm{PhD}$ degree $4.2 \%$. In relation to experience, Table 1 shows that $44.20 \%$ of the sample had 15 to 25 years of work experience, and $34.70 \%$ had experience between 7 and 15 years, and the others either had less than 7 years of experience $7.40 \%$, and more than 25 years of experience 


\section{MlMacrothink}

International Journal of Accounting and Financial Reporting

ISSN 2162-3082

2018, Vol. 8, No. 4

$13.70 \%$. Finally, In relation to Position, Table 1 shows that $41.10 \%$ of the sample had finance manager / Deputy Position, and 37.80\% had Board of directors Position and $21.10 \%$ of the sample had General Manager / Deputy Position.

\subsection{Goodness of Data}

Before testing the research hypotheses, it is important that the data collected were checked for validity and reliability. The content validity of the instrument was ascertained by obtaining expert opinions from seven lecturers in Jordanian universities. The construct validity of each variable, on the other hand, was ascertained by running factor analysis, which is elaborated below.

\subsection{Reliability of Measurement}

It is necessary to reliability test to check for the reliability of the survey instrument. According to Hair et al. (2010), the perfect measure of a concept needs more than one item. Moreover, according to Nunnally (1978), to assess the reliability of the survey instrument, the inter-item analysis can be used to test the scale's internal consistency. Hence, Cronbach's alpha is considered an adequate indicator of the internal consistency and the reliability of the survey instrument (Sekaran \& Bougie, 2010). The test shows that the Cronbach's alphas range from 0.863 to0.62, which exceed the minimum value of 0.60 to be acceptable. This means that the instruments used to measure the variable were acceptable and the data were later used for further analyses (Sekaran \& Bougie, 2010).

Table 2. Cronbach's alphas

\begin{tabular}{lll}
\hline NO. & Variables & $\begin{array}{l}\text { Cronbach's } \\
\text { Alpha }\end{array}$ \\
\hline 1 & agency theory & 0.741 \\
\hline 2 & stakeholder theory & 0.744 \\
\hline 3 & legitimacy theory & 0.775 \\
\hline 4 & signaling theory & 0.863 \\
\hline 5 & economic dimensions & 0.645 \\
\hline 6 & environmental dimensions & 0.622 \\
\hline 7 & social dimensions & 0.62 \\
\hline
\end{tabular}

\subsection{Criterion Validity}

Criterion validity analysis was conducted by using the dependent variables (economic dimensions, environmental dimensions, social dimensions) and the independent variable (agency theory, stakeholder theory, legitimacy theory, signaling theory). According to Hair et 
al. (2010), the tolerance (TOL) should be above 0.10 and the variance inflation factor (VIF) should be less than 10 to indicate no collinearity or multicollinearity among the independent variables. As shown in Table 3 there is no collinearity or multicollinearity among the variables of this study. Table 3 shows that the values of VIF ranged from (1.134 - 1.793) and the values of Tolerance range from $(0.558-0.882)$.

Table 3. Multicollinearity diagnoses of dependent and independent variables

\begin{tabular}{llll}
\hline NO. & Variables & Tolerance & VIF \\
\hline 1 & agency theory & 0.73 & 1.371 \\
2 & stakeholder theory & 0.882 & 1.134 \\
3 & legitimacy theory & 0.694 & 1.442 \\
4 & signaling theory & 0.558 & 1.793 \\
\hline
\end{tabular}

\section{Discussion of Results}

The researcher followed the descriptive approach for the data presentation and the analytical approach to the analysis of the results of the study.

\subsection{Averages and Standard Deviations}

Table 4. Arithmetical averages and standard deviations

\begin{tabular}{llll}
\cline { 2 - 3 } NO. & Variables & Average & Stand. D \\
\hline 1 & agency theory & 4.11 & 0.487 \\
2 & signaling theory & 4.095 & 0.417 \\
3 & legitimacy theory & 4.057 & 0.42 \\
4 & stakeholder theory & 3.634 & 0.646 \\
\hline Accounting Theory & 3.974 & 0.337 \\
\hline 5 & economic dimensions & 3.7 & 0.507 \\
6 & environmental dimensions & 3.952 & 0.44 \\
7 & social dimensions & 4.14 & 0.353 \\
\hline Sustainability Dimensions & 3.931 & 0.281 \\
\hline
\end{tabular}

Table 4 shows the arithmetical averages mean ranged between (3.634 to 4.110) from the point of view of all individuals, the highest arithmetic average for the (agency theory) with a 


\section{Mll Macrothink}

International Journal of Accounting and Financial Reporting

ISSN 2162-3082

2018, Vol. 8, No. 4

high mean (4.110) and to a high degree. On the other hand, the lowest arithmetic averages for the (stakeholder theory) with a high mean (3.91) and to a high degree. Secondly, the arithmetical averages mean ranged between (3.70 to 4.140) from the point of view of all individuals, the highest arithmetic average for the (social dimensions) with a high mean (4.140) and to a high degree. On the other hand, the lowest arithmetic averages for the (economic dimensions) with a high mean (3.70) and to a high degree.

\subsection{Hypotheses Testing}

Multiple Linear regressions were used, and the results were as follows:

H1. There is no statistically significant at the (0.05) level for the adoption of accounting theories (agency theory, signaling theory, legitimacy theory, stakeholder theory) on disclosing the economic dimensions in public shareholding companies.

Table 5. Results of analysis

\begin{tabular}{|c|c|c|c|c|c|c|c|c|c|c|}
\hline & $\begin{array}{l}\text { Model } \\
\text { Summ }\end{array}$ & & ANOV & & & Coefficient & & & & \\
\hline & $\mathrm{R}$ & $\mathrm{R}^{2}$ & $\mathrm{~F}$ & Df & $\begin{array}{l}\text { Sig } \\
\mathrm{F}^{*}\end{array}$ & Variables & B & $\begin{array}{l}\text { Std . } \\
\text { Error }\end{array}$ & $\mathrm{T}$ & $\begin{array}{l}\text { Sig } \\
\mathrm{t}^{*}\end{array}$ \\
\hline \multirow{4}{*}{$\begin{array}{l}\text { disclosure } \\
\text { the } \\
\text { economic } \\
\text { dimensions }\end{array}$} & \multirow{4}{*}{0.247} & \multirow{4}{*}{0.061} & \multirow{4}{*}{1.467} & \multirow{4}{*}{4} & \multirow{4}{*}{0.219} & $\begin{array}{l}\text { agency } \\
\text { theory }\end{array}$ & 0.023 & 0.139 & 0.167 & 0.868 \\
\hline & & & & & & $\begin{array}{l}\text { signaling } \\
\text { theory }\end{array}$ & 0.357 & 0.185 & 1.925 & 0.057 \\
\hline & & & & & & $\begin{array}{l}\text { legitimacy } \\
\text { theory }\end{array}$ & 0.254 & 0.165 & 1.539 & 0.127 \\
\hline & & & & & & $\begin{array}{l}\text { stakeholder } \\
\text { theory }\end{array}$ & 0.027 & 0.095 & 0.289 & 0.773 \\
\hline
\end{tabular}

* Significant at the 0.05 level (More than: $0.05=$ accept, Less than: $0.05=$ reject)

Table 5 shows the $\mathrm{R}$ value 0.247 this mean there is a positive related between disclosure the economic dimensions and adoption of accounting theory, the $\mathrm{R}^{2}$ of current study is 0.061 , this means that the current study explain only $6.10 \%$ of the variance in the (disclosure of the economic dimension), with other factors remaining constant, The calculated $F$ value is (1.467) and the significance level $(\mathrm{Sig}=0.219)$ is more than 0.05 indicating that the effect of this dimension is insignificant. 


\section{Mll Macrothink}

International Journal of Accounting and Financial Reporting

ISSN 2162-3082

2018, Vol. 8, No. 4

The table of coefficients showed that the B value at the agency theory 0.023 and the $t$ value 0.167 with a significance level more than 0.05 , indicating that the effect of this dimension is insignificant. And the $\mathrm{B}$ value at the signaling theory 0.357 and the $t$ value 1.925 with a significance level $(\mathrm{sig}=0.057)$ more than 0.05 , indicating that the effect of this dimension is insignificant. The $\mathrm{B}$ value at the legitimacy theory 0.254 and the $t$ value 0.189 with a significance level $(\mathrm{sig}=0.127)$ more than 0.05 , indicating that the effect of this dimension is insignificant. Finally, the B value at the stakeholder theory 0.027 and the $t$ value 0.289 with a significance level ( $\mathrm{sig}=0.773$ ) more than 0.05 , indicating that the effect of this dimension is insignificant.

Based on the above, we accept null hypothesis and reject the alternative hypothesis that:

There is no statistically significant at the (0.05) level for the adoption of accounting theories (agency theory, signaling theory, legitimacy theory, stakeholder theory) on disclosing the economic dimensions in public shareholding companies.

$\mathrm{H} 2$. There is no statistically significant at the (0.05) level for the adoption of accounting theories (agency theory, signaling theory, legitimacy theory, stakeholder theory) on disclosing the environmental dimensions in public shareholding companies.

Table 6. Results of analysis

\begin{tabular}{|c|c|c|c|c|c|c|c|c|c|c|}
\hline & $\begin{array}{l}\text { Model } \\
\text { Summ }\end{array}$ & & ANOV & & & Coefficient & & & & \\
\hline & $\mathrm{R}$ & $\mathrm{R} 2$ & $\mathrm{~F}$ & Df & $\begin{array}{l}\text { Sig } \\
\mathrm{F}^{*}\end{array}$ & Variables & B & $\begin{array}{l}\text { Std . } \\
\text { Error }\end{array}$ & $\mathrm{T}$ & $\begin{array}{l}\text { Sig } \\
t^{*}\end{array}$ \\
\hline \multirow{4}{*}{$\begin{array}{l}\text { disclosure } \\
\text { the } \\
\text { environmental } \\
\text { dimensions }\end{array}$} & \multirow{4}{*}{0.296} & \multirow{4}{*}{0.087} & \multirow{4}{*}{2.157} & \multirow{4}{*}{4} & \multirow{4}{*}{0.080} & $\begin{array}{l}\text { agency } \\
\text { theory }\end{array}$ & 0.051 & 0.125 & 0.412 & 0.681 \\
\hline & & & & & & $\begin{array}{l}\text { signaling } \\
\text { theory }\end{array}$ & 0.390 & 0.167 & 2.339 & 0.022 \\
\hline & & & & & & $\begin{array}{l}\text { legitimacy } \\
\text { theory }\end{array}$ & 0.342 & 0.148 & 2.308 & 0.023 \\
\hline & & & & & & $\begin{array}{l}\text { stakeholder } \\
\text { theory }\end{array}$ & 0.026 & 0.085 & 0.308 & 0.759 \\
\hline
\end{tabular}

* Significant at the 0.05 level (More than: $0.05=$ accept, Less than: $0.05=$ reject)

Table 6 shows the $R$ value 0.296 this mean there is a positive related between disclosure the environmental dimensions and adoption of accounting theory, the $\mathrm{R}^{2}$ of current study is 0.087 , this means that the current study explain only $8.70 \%$ of the variance in the (disclosure of the 


\section{Mll Macrothink}

International Journal of Accounting and Financial Reporting

ISSN 2162-3082

2018, Vol. 8, No. 4

environmental dimension), with other factors remaining constant, The calculated $\mathrm{F}$ value is 2.157 and the significance level $(\mathrm{Sig}=0.080)$ is more than 0.05 indicating that the effect of this dimension is insignificant.

The table of coefficients showed that the $\mathrm{B}$ value at the agency theory 0.051 and the $\mathrm{t}$ value 0.412 with a significance level $(\mathrm{sig}=0.681)$ more than 0.05 , indicating that the effect of this dimension is insignificant. And the $\mathrm{B}$ value at the signaling theory 0.390 and the $t$ value 2.339 with a significance level $(\mathrm{sig}=0.022)$ less than 0.05 , indicating that the effect of this dimension is significant. The $\mathrm{B}$ value at the legitimacy theory 0.342 and the $\mathrm{t}$ value 2.308 with a significance level ( $\mathrm{sig}=0.023$ ) less than 0.05 , indicating that the effect of this dimension is significant. Finally, the B value at the stakeholder theory 0.026 and the $t$ value 0.308 with a significance level $(\mathrm{sig}=0.759)$ more than 0.05 , indicating that the effect of this dimension is insignificant.

Based on the above, we accept null hypothesis and reject the alternative hypothesis that:

There is no statistically significant at the (0.05) level for the adoption of accounting theories (agency theory, signaling theory, legitimacy theory, stakeholder theory) on disclosing the environmental dimensions in public shareholding companies.

H3. There is no statistically significant at the (0.05) level for the adoption of accounting theories (agency theory, signaling theory, legitimacy theory, stakeholder theory) on disclosing the social dimensions in public shareholding companies.

Table 7. Results of analysis

\begin{tabular}{|c|c|c|c|c|c|c|c|c|c|c|}
\hline & $\begin{array}{l}\text { Model } \\
\text { Summ }\end{array}$ & & ANOVA & & & Coefficient & & & & \\
\hline & $\mathrm{R}$ & $\mathrm{R} 2$ & F & Df & $\begin{array}{l}\text { Sig } \\
\mathrm{F}^{*}\end{array}$ & Variables & B & $\begin{array}{l}\text { Std . } \\
\text { Error }\end{array}$ & $\mathrm{T}$ & $\begin{array}{l}\text { Sig } \\
\mathrm{t}^{*}\end{array}$ \\
\hline \multirow{4}{*}{$\begin{array}{l}\text { disclosure } \\
\text { the } \\
\text { social } \\
\text { dimensions }\end{array}$} & \multirow{4}{*}{0.731} & \multirow{4}{*}{0.534} & \multirow{4}{*}{25.751} & \multirow{4}{*}{4} & \multirow{4}{*}{0.000} & $\begin{array}{l}\text { agency } \\
\text { theory }\end{array}$ & 0.351 & 0.061 & 5.752 & 0.000 \\
\hline & & & & & & $\begin{array}{l}\text { signaling } \\
\text { theory }\end{array}$ & 0.391 & 0.082 & 4.789 & 0.000 \\
\hline & & & & & & $\begin{array}{l}\text { legitimacy } \\
\text { theory }\end{array}$ & 0.156 & 0.073 & 2.145 & 0.035 \\
\hline & & & & & & $\begin{array}{l}\text { stakeholder } \\
\text { theory }\end{array}$ & 0.018 & 0.042 & 0.419 & 0.676 \\
\hline
\end{tabular}

* Significant at the 0.05 level (More than: $0.05=$ accept, Less than: $0.05=$ reject) 


\section{Mll Macrothink}

International Journal of Accounting and Financial Reporting

ISSN 2162-3082

2018, Vol. 8, No. 4

Table 7 shows the $\mathrm{R}$ value 0.731 this mean there is a positive related between disclosure the social dimensions and adoption of accounting theory, The $\mathrm{R}^{2}$ of current study is 0.534 , this means that the current study explain only $53.4 \%$ of the variance in the (disclosure of the social dimension), with other factors remaining constant, The calculated $F$ value is 25.751 and the significance level $(\mathrm{Sig}=0.000)$ is less than 0.05 indicating that the effect of this dimension is significant.

The table of coefficients showed that the $\mathrm{B}$ value at the agency theory 0.351 and the $\mathrm{t}$ value 5.752 with a significance level $(\mathrm{sig}=0.000)$ less than 0.05 , indicating that the effect of this dimension is significant. And the B value at the signaling theory 0.391 and the $t$ value 4.789 with a significance level $(\mathrm{sig}=0.000)$ less than 0.05 , indicating that the effect of this dimension is significant. The $\mathrm{B}$ value at the legitimacy theory 0.156 and the $\mathrm{t}$ value 2.145 with a significance level $(\mathrm{sig}=0.035)$ less than 0.05 , indicating that the effect of this dimension is significant. Finally, The B value at the stakeholder theory 0.018 and the $t$ value 0.419 with a significance level $(\mathrm{sig}=0.676)$ more than 0.05 , indicating that the effect of this dimension is insignificant.

Based on the above, we accept alternative hypothesis and reject the null hypothesis that:

There is statistically significant at the (0.05) level for the adoption of accounting theories (agency theory, signaling theory, legitimacy theory, stakeholder theory) on disclosing the social dimensions in public shareholding companies.

Test the main hypothesis:

There is no statistically significant at the (0.05) level for the adoption of accounting theories (agency theory, signaling theory, legitimacy theory, stakeholder theory) on disclosing of dimensions sustainability (economic dimension, environmental dimension, and social dimension) in public shareholding companies.

Table 8. Results of analysis

\begin{tabular}{|c|c|c|c|c|c|c|c|c|c|c|}
\hline & \multicolumn{2}{|c|}{$\begin{array}{l}\text { Model } \\
\text { Summary }\end{array}$} & \multicolumn{3}{|c|}{ ANOVA } & \multicolumn{5}{|c|}{ Coefficient } \\
\hline & $\mathrm{R}$ & $\mathrm{R} 2$ & $\mathrm{~F}$ & Df & $\begin{array}{l}\text { Sig } \\
\mathrm{F}^{*}\end{array}$ & Variables & B & $\begin{array}{l}\text { Std . } \\
\text { Error }\end{array}$ & $\mathrm{T}$ & $\begin{array}{l}\text { Sig } \\
t^{*}\end{array}$ \\
\hline \multirow{2}{*}{$\begin{array}{l}\text { disclosure of } \\
\text { sustainability } \\
\text { dimensions }\end{array}$} & \multirow{2}{*}{0.476} & \multirow{2}{*}{0.227} & \multirow{2}{*}{6.601} & \multirow{2}{*}{4} & \multirow{2}{*}{0.000} & $\begin{array}{l}\text { agency } \\
\text { theory }\end{array}$ & 0.116 & 0.063 & 1.842 & 0.069 \\
\hline & & & & & & $\begin{array}{l}\text { signaling } \\
\text { theory }\end{array}$ & 0.290 & 0.084 & 3.462 & 0.001 \\
\hline
\end{tabular}




\begin{tabular}{lllll}
$\begin{array}{l}\text { legitimacy } \\
\text { theory }\end{array}$ & 0.165 & 0.075 & 2.206 & 0.030 \\
\hline $\begin{array}{l}\text { stakeholder } \\
\text { theory }\end{array}$ & 0.008 & 0.043 & 0.188 & 0.851 \\
\end{tabular}

* Significant at the 0.05 level (More than: $0.05=$ accept, Less than: $0.05=$ reject)

Table 8 shows the $\mathrm{R}$ value 0.476 this mean there is a positive related between disclosure of dimensions sustainability and adoption of accounting theory, The $\mathrm{R}^{2}$ of current study is 0.227 , this means that the current study explain only $22.7 \%$ of the variance in the (disclosure of dimensions sustainability), with other factors remaining constant, The calculated $\mathrm{F}$ value is 6.601 and the significance level $(\mathrm{Sig}=0.000)$ is less than 0.05 indicating that the effect of this dimension is significant.

The table of coefficients showed that the B value at the agency theory 0.116 and the $t$ value 1.842 with a significance level $(\mathrm{sig}=0.069)$ more than 0.05 , indicating that the effect of this dimension is insignificant. And the $\mathrm{B}$ value at the signaling theory 0.290 and the $t$ value 3.462 with a significance level $(\mathrm{sig}=0.001)$ less than 0.05 , indicating that the effect of this dimension is significant. The $\mathrm{B}$ value at the legitimacy theory 0.165 and the $t$ value 2.206 with a significance level ( $\mathrm{sig}=0.030$ ) less than 0.05 , indicating that the effect of this dimension is significant. Finally, the B value at the stakeholder theory 0.008 and the $t$ value 0.188 with a significance level $(\mathrm{sig}=0.851)$ more than 0.05 , indicating that the effect of this dimension is insignificant.

Based on the above, we accept alternative hypothesis and reject the null hypothesis that:

There is statistically significant at the (0.05) level for the adoption of accounting theories (agency theory, signaling theory, legitimacy theory, stakeholder theory) on disclosing of sustainability dimensions (economic dimension, environmental dimension, and social dimension) in public shareholding companies.

\section{Conclusion and Recommendations}

\subsection{Conclusions}

Based on the analysis of the study data and the hypothesis test, the study reached the following results:

1. The results of the analysis showed that trends of the respondents about the existence of the adoption of accounting theories (agency theory, signaling theory, legitimacy theory, stakeholder theory) in the public shareholding companies with a high level of relative importance. In addition, the results showed that agency theory was first in terms of relative importance, while the stakeholder theory came in last ranking.

2. The results of the analysis showed that trends of the respondents about the existence of the disclosing of sustainability dimensions in the public shareholding companies with a high level of relative importance. In addition, the results showed that disclosing the social dimensions was first in terms of relative importance, while the disclosing the economic dimensions came in last ranking. 


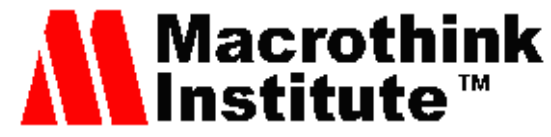

International Journal of Accounting and Financial Reporting

ISSN 2162-3082 2018, Vol. 8, No. 4

3. The results of the main hypothesis test showed that there is a existence to adopt of accounting theories (agency theory, signaling theory, legitimacy theory, stakeholder theory) on disclosing of sustainability dimensions (economic dimension, environmental dimension, and social dimension) in public shareholding companies, when studying the dimensions combined, The significant effect show at ( agency theory, signaling theory, legitimacy theory) While the insignificant effect show in the theory of stakeholders and This does not negate the importance of dimension. But shows the importance of dimensions with a significant impact. This result proved the opinion of the respondents.

\subsection{Recommendations}

Depending on the results, the researcher the study recommended the need to increase the commitment of public shareholding companies to apply the principle of transparency and disclosure of their environmental, social and economic activities, as well as recommending the management of public shareholding companies to the necessity of diversity in the interests of all parties associated with them.

\section{References}

Akhter, S., \& Dey, P. K. (2017). Sustainability Reporting Practices: Evidence from Bangladesh. International Journal of Accounting and Financial Reporting, 7(2), 61.

Bashatweh, A. D. (2018, September 1-3). The effect of disclosure of dimensions sustainability on profitability of the Jordanian Bank - Applied Study on Jordanian Islamic Banks -2nd International Conference of Industrial and Service Organizations Management. Hurghada, Egypt.

Bhattacharya, S., \& Ritter, J. R. (1983). Innovation and Communication: Signaling with Partial Disclosure. Review of Economic Studies, 50, 331-346.

Deegan, C. (2002). Introduction. Accounting, Auditing \& Accountability Journal, 15(3), 282-311.

Deegan, C., \& Unerman, J. (2011). Financial Accounting Theory: European Edition UK Higher Education Business Accounting. McGraw-Hill.

Global Reporting Initiative (GRI). (2014). Sustainability Reporting Guidelines, Version 4.0.

Hahn, R., \& Kühnen, M. (2013). Determinants of sustainability reporting: a review of results, trends, theory, and opportunities in an expanding field of research. Journal of Cleaner Production, 59, 5-21.

Hair, J. F., Black, W. C., Babin, B. J., Anderson, R. E., \& Latham, R. (2010). Multivariate Data Analysis (7th ed.). New Jersey: Pearson.

Hörisch, J., Freeman, R. E., \& Schaltegger, S. (2014). Applying Stakeholder Theory in Sustainability Management. Organization \& Environment, 27(4), 328-346.

Hummel, K., \& Schlick, C. (2016). The relationship between sustainability performance and sustainability disclosure - Reconciling voluntary disclosure theory and legitimacy theory. Journal of Accounting and Public Policy, 35(5), 455-476. 


\section{Macrothink}

International Journal of Accounting and Financial Reporting ISSN 2162-3082 2018, Vol. 8, No. 4

Jizi, M., Salama, A., Dixon, R., \& Stratling, R. (2014). Corporate Governance and Corporate Social Responsibility Disclosure: Evidence from the US Banking Sector. Journal of Business Ethics, 25(4), 601-615.

Nunnally, J. C. (1978). Psychometric Theory (2nd ed.). New York: McGraw-Hill.

Sekaran, U., \& Bougie, R. (2010). Research Methodology for Business: A Skill Building Approach (5th ed.). Australia: Wiley \& Sons.

Şener, İ., Varoğlu, A., \& Karapolatgil, A. A. (2016). Sustainability Reports Disclosures: Who are the Most Salient Stakeholders?. Procedia - Social and Behavioral Sciences, 235, 84-92.

Shahin, A. (2011). Accounting Theory: An Analytical and Applied Conceptual Framework (1st ed.). Gaza, Palestine: Aafaq for Publish \& Distribution.

Thomas, L. \& Vos, C. (2012). Sustainability Reporting with an Environmental Focus: A Comparative Analysis from the Logistics Industry. Lund University School of Economics and Management, Sweden.

World Commission on Environment and Development (WCED). (1987). Our Common Future. Oxford: Oxford University Press.

\section{Copyright Disclaimer}

Copyright for this article is retained by the author(s), with first publication rights granted to the journal.

This is an open-access article distributed under the terms and conditions of the Creative Commons Attribution license (http://creativecommons.org/licenses/by/4.0/) 